\title{
iGeneration's Communication Psychology Facing Covid-19 In Terms of Cognitive Dissonance
}

\section{Psikologi Komunikasi iGeneration Menghadapi Pandemi Covid-19 Ditinjau dari Disonansi Kognitif}

\author{
Dianingtyas Putri*, Suharyanti, Dyah Ajeng \\ Universitas Bakrie, Jl. H. Rasuna Said Kav. C-22, Kuningan, 12920, Jakarta, Indonesia \\ *Corresponding author, e-mail: dianingtyas.putri@bakrie.ac.id
}

\begin{abstract}
The Covid-19 pandemic has a broad impact on various aspects and lines. One of them is that the country's economy has not moved forward as before. The unemployment rate increase among the iGeneration who have just graduated from college feels confused and anxious because they have not found a job, thus negatively affected them. This research aims to analyze the iGeneration in facing the impact of Covid-19 pandemic in cognitive dissonance theory by linking interpersonal communication through communication psychology. This research was a case study of a conservative generation of 22 years of age with excellent academic achievements. The results show that of the three mental mechanisms that consist of selective prevents dissonance, post-decision dissonance creates a need for reassurance, and minimal justification for action induces a shift in attitude, the informants have different perspectives and perceptions that affect self-efficacy on the issue as cognitive dissonance.
\end{abstract}

Keywords: Cognitive issonance theory; Communication psychology; iGeneration; Interpersonal communication; Pandemic Covid-19

\begin{abstract}
Abstrak
Pandemi Covid-19 memiliki dampak yang luas di berbagai aspek, salah satunya adalah roda ekonomi di negara ini belum bergerak maju seperti sedia kala. Tingkat pengangguran bagi iGeneration yang baru lulus kuliah merasa bingung dan cemas karena belum mendapatkan pekerjaan sehingga menimbulkan efek psikologis pada diri mereka. Tujuan penelitian ini adalah untuk menganalisis bagaimana iGeneration dalam menghadapi dampak pandemi Covid-19 ditinjau dari teori disonansi kogntif dengan mengaitkan komunikasi antarpribadi dalam peran psikologi komunikasi. Metode penelitian menggunakan studi kasus pada iGeneration konservatif, dimana rentan usianya 20-22 tahun, didukung memiliki prestasi secara akademik yang sangat baik. Hasil menunjukkan bahwa dari tiga mekanisme mental yang terdiri dari selective prevents dissonance, post decision dissonance creates a need for reasurance, dan minimal justification for action induces a shift in attitude, para informan memiliki perspektif dan persepsi yang berbeda sehingga memengaruhi efikasi diri terhadap isu tersebut sebagai disonansi kognitif.
\end{abstract}

Kata Kunci: iGeneration; Komunikasi antarpribadi; Pandemi Covid-19; Psikologi komunikasi; Teori disonansi kognitif 


\section{Introduction}

The COVID-19 pandemic has been hitting this country since February 2020. As a result, President Joko Widodo (Jokowi) decided to create large-scale social distancing or what is known as the implementation of large-scale social distancing (PSBB). Subsequently, the Governor of DKI Jakarta Anies Baswedan imposed the PSBB for two weeks and continues until now. The reason he gave was quoted from detiknews.com, which is, based on epidemiological data during the implementation of the PSBB, the COVID-19 outbreak in DKI Jakarta was more controlled and headed for the safe category. The purpose of the PSBB being extended is as a precautionary measure, so it is not increasing again (Nafi-an, 2020). Anies conveyed this through the press release of the Jakarta Provincial Government PPID on Sunday last November. However, the effects of the COVID-19 pandemic are prevalent and have paralyzed almost all aspects down to the line. There are two aspects that concern President Jokowi: the health aspect and the economic aspect, conveyed a few times ago when chairing a Plenary Cabinet Session with Health Management and Economic Recovery for Strengthening Reforms 2021. In other words, the main focus is on health in handling COVID-19.

However, the economic aspect has also experienced a drastic decline. This was stated by the Minister of Finance, Sri Mulyani Indrawati, when she spoke before the DPR Banggar regarding the pandemic, the systematics of COVID-19 Perrppu (Act), and the fiscal policies pursued (Putri, 2020). Here she states that the pandemic's impact is severe enough to make the most stringent scenario that Indonesia may have to face, wherein the second week of March, the economic pulse was still good. In fact, in the second week, there was a change resulting in a drop in tax revenue (Limilia \& Pratamawaty, 2020). This means that if this continues in the next quarter, this country will enter the brink of recession. The Central Statistics Agency (BPS) reported that Indonesia's gross domestic product (GDP) in the third quarter of 2020 was minus 3.49 percent (year on year). This is proof that Indonesia has officially entered the abyss of recession. After the second quarter of 2020, the Republic of Indonesia's economy was also gloomy. The recession also affected the fate of millions of workers who were laid off and laid off.

The condition of the COVID-19 pandemic does not only impact a significant scope but also affects a person's psychology and physiology. Why? This situation creates anxiety and distress for every individual who is carrying out their activities during this pandemic, causing a global mental health crisis (Rosyanti \& Hadi, 2020, pp. 112-114). This health crisis causes psychosomatics in a person, such as diarrhea, continuous dizziness, lack of appetite, difficulty sleeping, etc. The consequences of this can endanger people. Therefore, it needs support from family and closest friends (significant others). Building an effective interpersonal communication interaction relationship is an effort to provide reinforcement both psychologically and physiologically. Devito (2016) and (Lusiawati, 2019, p. 485) explain that interpersonal communication is the verbal and nonverbal interaction between interrelated or interdependent people. Interpersonal communication is "connected" in nature but influences one another. One person's actions will have consequences for others. Then, interpersonal communication is an inherent or inseparable relationship. The statement's purpose is how communication with the people closest to us can affect the built relationship. Understanding the pandemic conditions that have been previously mentioned will create a healthy and conducive communication climate that can maintain one's emotional stability through interpersonal communication interaction patterns. 
The above phenomenon gives anxiety and fear to new graduates whose age is 2022 years old, referred to as generation $Z$. Then, when they finish their studies, the next step is looking for work. The article titled "Job Seeker's Behavior By Fresh Graduate Under Wilson's Model Analysis" states that fresh graduates look for job information (Nihayati \& Laksmi, 2020, p. 55). This behavior is called information behavior which focuses on an activity carried out by a person in finding the information needed in this job. In a sense, this information behavior can arise when the need is urgent. Furthermore, this need for information does not directly become information behavior by a person but is motivated by the pressures and impulses in his life.

Job information is obtained in online media and offline media, namely closest friends, relatives, job fairs, labor recruitment agencies, printed media (Nihayati \& Laksmi, 2020, pp. 56-57). Meanwhile, online media from electronic media, internet media, and social media. The existence of the COVID-19 pandemic has increased the unemployment rate for those graduates at both undergraduate and diploma levels. The emergence of anxiety and self-fear can affect self-concept, self-esteem, self-efficacy. The results of previous research by Gloria A. Tangkeallo stated a significant relationship between self-efficacy and future orientation of final year students (Tangkeallo et al., 2014, pp. 29-30).

Furthermore, their research shows a significant positive correlation between selfefficacy and future orientation towards final year students at X University. Then, the correlation or relationship that occurs is positive. Namely, when self-efficacy increases, the future orientation of students tends to be more transparent. What is more evident here is that a person can determine his efforts to achieve something he wants, and he can meet the resilience that a person has in facing obstacles by looking for a middle way. This is influenced by one of the factors that influence it, namely cognitive development. All generations feel anxiety without exception. The anxiety felt by the $\mathrm{Z}$ generation is a condition that is not balanced between what they think and what they think. This imbalance can be called dissonance (Fadholi et al., 2020, p. 4), and the opposite of a balanced condition is called consonance. Dissonance occurs when a person attempts to deny the element, followed by the next part, where the denial is also carried out on the reality he faces. This is also called the level of dissonance, where the increasing level will determine the individual's actions. In other words, this action was carried out to reduce his sense of dissonance. Festinger (Yahya \& Sukmayadi, 2020, pp. 481-482) stated several measures to reduce dissonance, namely (1) changing the elements of behavior; (2) changing the cognitive aspects of the environment; (3) add new cognitive elements. From the three efforts, it can be seen that a person will use strategies to change what he thinks and reduce what he feels. This study uses a communication psychology approach that looks at how the response occurs when communication interactions occur. It has been explained that the imbalance experienced by a person can form an increase in dissonance in him. Therefore someone will look for efforts as a strategy to reduce his dissonance with the response given from the recipient of the message and at the same time the actor known as the communicant (Rakhmat, 2015, p. 24).

Generation $\mathrm{Z}$ is different from other generations. Generation $\mathrm{Z}$, known as iGeneration or the net generation, has something in common with generation $\mathrm{Y}$, where these two generations seek various information from internet media (Linnes \& Metcalf, 2017). They are also able to apply it in all their activities or activities at one time. Therefore, it is no wonder they are friends of the internet media because they often use 
it to meet their needs for all aspects. The characteristics of iGeneration are that generation is different from previous generations. They are fluent in technology, the intensity of their social interactions is more interaction on social media, they are expressive, multitasking, and quickly moves from one thought to other thoughts and pleased to share contents (Wijoyo et al., 2020, pp. 1-2). It has been said that generation $\mathrm{Z}$ is expressive, but Amanda Slavin (Rachmawati, 2019, p. 23; Slavin, 2015) finds iGeneration wants to be recognized, what their opinions are being heard $\mathrm{He}$ added that technology is part of their identity, but they do not have problem-solving skills. In other words, this generation is adept at using technology, but understanding the meaning of each uploaded content, doing the analysis is still lacking.

This generation also likes to share every moment of their life with their social media. Still, they do not think about how it will impact the long term, especially their psychological impact (Qurniawati \& Nurohman, 2018, p. 70). Self-control in the desire to always share momentum with netizens is part of managing human emotions. Abraham Maslow describes conditions into five-level basic needs through the hierarchy of needs theory of motivation theory: physiological needs, security needs, needs and love, self-esteem needs, and self-actualization needs (Ginting, 2018, pp. 225-226). Regarding the sharing of momentum carried out by iGeneration, they enter the need for self-actualization (Wijoyo et al., 2020). The generation eagers to spread its existence because if its existence is known, it is believed to increase their self-esteem. Thus, they share some momentum and emotions such as being sad, anxious, happy, and other emotions. This is reflected in the social media Twitter, where users share what they think and feel can represent similar backgrounds.

The strategy taken is that someone will look for information that can support it. Here the information will be sorted or re-selected. This sorting will be influenced by selective attention, selective exposure, particular interpretation, and selective retention. Selective attention is a unique and specific sorting in certain parts. In the process, there is an attention mechanism in one's cognitive realm. This can only be done by the human mind and cannot be done by machine algorithms. Meanwhile, selective exposure is the sorting made by a person of a message or information that confirms his belief. Then, a method for reducing dissonance is the particular interpretation, in which the ambiguous way of interpreting the information received can appear consistent with the opinion in thought. Finally, reducing dissonance is done with selective retention, when individuals only want to remember information that is one frequency and even with their beliefs (Devito, 2016; Lusiawati, 2019). Thus, information or supporting messages will reinforce what he thinks and feels. This means that in the existence of internet media other than the community, peers become a reference for reinforcement for a person to justify an opinion that what the individual feels is correct. If it is related to the object of this research, namely the tendency of generation $\mathrm{Z}$ to be susceptible to stress in facing the current pandemic conditions, the efforts being made are finding ways to reduce their dissonance with internet media such as YouTube, podcasts, Instagram, Twitter which represent what they think and feel. 


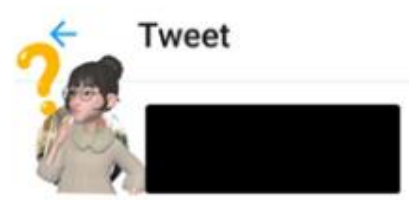

yok yok jobseeker yang semangat cari kerja, saingan dah bertambah lagi nih alias banyak lulusan baru pada kelar wisudaan
Tweet

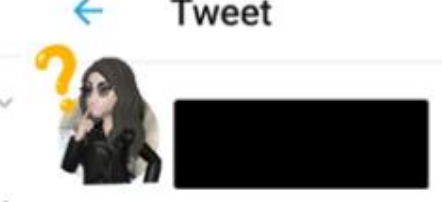

Cari kerja susah yaa, dan tiap tahun ada banyak lulusan baru

Figure. 1. fresh graduate Tweet for Job Seeker (source: Twitter.com)

The self-control of emotions is essential because if self-control is lacking, it could affect the person (self). Self has a basic concept of how a person reacts to the phenomenal world. According to William H. Fitts (Shafira \& Soedirham, 2017, p. 156), the self that is seen, experienced, and felt is a self-concept process. Carl R. Rogers, in his theory of personality theory, stated that self contains four aspects regarding how a person can observe himself, think about himself, assess himself, and how someone must try in various ways to be able to perfect and defend himself (Setiyani, 2017, p. 240). The central concept of this theory is that self develops and can grow through the interaction of an organism with its environment, self pursues consistency which includes wholeness, unity, and harmony, and finally, the self can change as a result of maturation or the learning process in its environment (Rosito, 2018). Self is the whole of the human being itself, and sometimes self is not realized by someone because there are a conception and perception of self, which is obtained and learned throughout his life supported by the person's experiences, interactions with other people and with the external world (Srisayekti \& Setiady, 2015, p. 144). This is what is not uncommon for cognitive dissonance psychologically.

According to Leon Festinger (Achmad et al., 2019, p. 21), cognitive dissonance is a feeling someone has when they find themselves doing something that is not following what they know or has an opinion that is not shared with the idea of others they hold according to their principles. Festinger also conveyed that three factors cause dissonance, namely self-consistency (the rational animal), the desire to be consistent between one's beliefs and actions taken. Second, personal responsibility for bad outcomes (the new look) is that dissonance can also occur when we have personal responsibility for bad results. When we have a significant obligation, the donations that occur are too large, so that there tends to be a sense of guilt in us, which makes us feel uncomfortable with what we have done. Third, self-affirmation dissipates dissonance, where the dissonance that occurs in humans always encourages us to justify our actions by changing our attitudes (Sarwono, 2010; Sutarmanto, 2017, p. 3). When they experience dissonance, they will tend to think positive things about themselves to divert the dissonance that happens to them. Festinger (Metin \& Camgoz, 2011, p. 133) hypothesized three mental mechanisms to ensure that their actions and behaviors were in line. The hypothesis consists of selective prevents dissonance, post-decision dissonance creates a need for reassurance, and minimal justification for action induces a shift in attitude. This is what iGeneration does in that they seek efforts on what they think and feel to be consistent and be in harmony with their thoughts, beliefs, emotions, values, and attitudes. 
The results of previous studies related to cognitive dissonance theory on premarital sex behaviour show that of the informants are adolescents who are members of certain peer groups such as dance groups, recitation groups, discussion groups. This hobby group has similarities; they experience confusion, anxiety, and discomfort related to permissive attitudes towards premarital sex behavior. There is a permissive attitude when responding to this. The communication process in achieving cognitive consistency is carried out in three forms (Hutagalung, 2016, pp. 74-75). When they experience confusion, they seek other information support that will strengthen themselves by reducing the importance of permissiveness to premarital sex behavior, which does not need to be lived and must be ignored because it can damage life in the future. This theory is influenced by psychology, and Griffin categorizes it into the sociopsychological tradition (Griffin, 2012). When communication between humans occurs, they have cultural values to manage the information they receive and interpret.

Humans do not automatically respond to their environment, but depending on how they think and interpret them (Stephen W. Littlejohn, 2009, p. 97), this is known as a cognitive structure (schema). Furthermore, the schema is processed by human cognition. This process can affect the self-self in humans (Reddan, 2015, p. 292). Based on his cognitive development, a person shows flexible, individualistic thinking and will apply various moments of his experience to prepare and self-confidence in making multiple decisions he chooses (Rahmi, 2019, p. 15). Thus, this decision also has a significant effect on future self-efficacy to be realized. The higher the human selfefficacy, the person concerned tends to have a more evident future orientation.

Meanwhile, this research focuses on how iGeneration or Generation $\mathrm{Z}$ faces the COVID-19 pandemic in cognitive dissonance theory with three mental mechanisms. The iGeneration chosen are those of the conservative $\mathrm{Z}$ generation. Why? Their way of thinking and feeling is different from that of the non-conservative generation $\mathrm{Z}$. This research also wants to describe the cognitive dissonance this generation has regarding the efforts they made to face the COVID-19 pandemic regarding work, as stated earlier that job opportunities during this pandemic are minimal and many companies are making reductions bulk. They have in common that they feel uncomfortable in this situation. This is what causes increased self-anxiety so that it can affect self-efficacy. Therefore, making them make social comparisons with their peers through social media, both Instagram and Twitter. Social media is used as their reference, and they seek information to strengthen themselves. They are students who have just graduated in 2020.

\section{Method}

The method used was a case study. Creswell (1998) in (Pambayun, 2013, p. 245) stated that case study research is not a methodological choice but an option to find what needs to be researched. Thus, this research used a qualitative approach with the instrumental case study research method, which research a specific case unique to understand issues and develop and refine theories. This case study was used to better understand an issue by reformulating a more theoretical explanation. The research process was carried out in-depth on the issue or case being studied. Also, Creswell (1998) (Pambayun, 2013, p. 246) explains that several criteria are said to be case studies. The objects appointed as cases are the events, situations, processes, programs, and activities.

Research is then called a case study if the research process is carried out in-depth 
and thoroughly on the cases being studied, then follows the case study structure, which consists of problems, contexts, issues, and lessons that can be taken. Moreover, the research object was iGeneration fresh graduates who have not got a job due to the COVID-19 pandemic, with a communication psychology approach analyzed using cognitive dissonance theory. Meanwhile, the research subjects were informants with the age category of 20-22 years. The criteria were fresh graduate, iGeneration conservative students who had not received permanent work during the COVID-19 pandemic. This research used purposive sampling with three informants, namely iGeneration conservative, for generation $\mathrm{Z}$ who has a mindset, a point of view that is still based on authentic values, such as family, religion, and maintaining the prevailing traditions.

In-depth interviews and observations were carried out face-to-face as the data collection technique to obtain various informants' information (Rashid et al., 2019). The in-depth interview method uses a semi-structured way, where the researcher had prepared a list of questions for the informants. The plan was developed spontaneously during the interview process (Prihatsanti et al., 2018). Other data collection techniques were also assisted by media such as WhatsApp and google meet, and this was due to the COVID-19 pandemic, which obliged large-scale social restriction.

\section{Results and Discussion}

Until now, COVID-19 is still ongoing. The impact felt for those who undergo are worrying and insecure. The characteristics of iGeneration that are prone to stress support the effects, one of which is the increased self-anxiety associated with after college and the question 'where do you go after college?' It has been stated in the background that this country is facing the abyss of recession. This is what makes many companies "economize" so that they cannot accept new employees. Many companies that take internships are not full-timers. As a result, many 2020 fresh graduates have not found jobs until now.

Through in-depth interviews, fresh graduates with a GPA above 3.2 had achievements while being active in college. They are iGenerations who comply with the rules of their respective families. Also, the informants have something in common: it is not the modern $\mathrm{Z}$ generation in terms of their lifestyle. Another similarity among these informants is that they both tend to be simple in following their lifestyle and very much obey the values of politeness to their parents that influence them until now. Therefore, excessive expectations are also given by people around them. They cause mental burdens that they continue to feel because they have not found a job that matches the expectations of the people around them. Therefore, the researchers call it iGeneration conservative, with an average age of 20-22 years. It turns out that there is a COVID-19 pandemic. They feel and think that they are not following the general assessment, namely working in a company. This is because the self-measuring value set by the informants is that a person will be considered successful and liked by his/her closest community (family), in this case, if they work in a well-known company. Slowly this feeling of restlessness spreads, making her anxiety increase. Leon Festinger (1957) stated that humans would look for efforts when their cognitive state is disrupted. These efforts are carried out as motivation to achieve consonance (Fadholi et al., 2020, pp. 67).

Furthermore, based on in-depth interviews, the informants admit to looking for efforts that are a form of mental balance in various ways, including social media such as YouTube, Instagram, and Twitter. Here, they are looking for multiple platforms to 
strengthen themselves, as stated by informant Aul saying, “...lately I like watching the YouTube of Mba Analisa Widianingrum, she is a psychologist. For me, they were watching it can answer most of the problems that I face, such as inner children, teaching self-love, etc.". Not only that, but informant Aul also added, "Aul also likes listening to Daritadi's podcast, let's be Dito, Ayu, Tara, and his wife. The reason why? Because when I listen to their Spotify because it's funny, I can get a little perspective on the millennial marriage world's twists and turns. However, it is not far from our parents' advice, like financial, health, in-laws, children, etc. I guess....". The activity carried out by informant Aul is an effort to motivate to find conditional information, where if someone experiences dissonance. Grifin explains that Festinger divides into three mental mechanisms that people use to ensure that their actions and attitudes are in harmony. Dissonance researchers refer to them as selective exposure, post-decision dissonance, and minimal justification (Griffin, 2012, p. 219). The following is an explanation and is linked to the findings with the informants:

\section{Selective Prevents Dissonance}

This hypothesis describes people who tend to avoid information that can create cognitive discrepancies because it is not following their beliefs. In this case, what was done by informant Aul, was sorting out the information that made him uncomfortable. The statement made by informant Aul, "Aul recently watched YouTube Mba Analisa Widianingrum, compared to Instagram social media, because according to my perspective, IG it is just visual and just like imaging. It is different from YouTube that I watch. Then, Aul also likes Podcasts ... but it is only sound, right? Aul needs a platform that can explain and practice that too. I think so..." Not only that, but informant May also stated through her statement that "...I like watching YouTube Menjadi Manusia. In this channel, the content can relate with my current condition..." In other words, what he is doing here is looking for information that can strengthen herself, because since she graduated from one of the X Universities, informant May feels that she is not valuable. She also makes social comparison when using Instagram social media. He likes to visit the IG stories of his peers to find out about their activities. However, what she gets is feeling insecure, so that this action creates self-anxiety in him. Informant Han said the same thing, where since graduating, she has not had a job call. She also wondered at first she saw the impact of the COVID-19 pandemic. Still, when she saw the activities or activities carried out by his peers, whether one alma mater or not, informant Han felt anxious and anxious, so she considered herself that I don't have the competence myself, the following statement is "... why am I still here, while the friends I know are already at work, I think. This is what makes me feel small. Even though I have graduated, how come it become like this".

Informant Han, to avoid the information that made her uncomfortable, so selects the information she receives then she looks for efforts by looking for information that is in line with what she believes and ignores facts that can destroy what she thinks. She chooses to find a way to channel herself using the Blog platform and opens up to find friends who have the same background as her thoughts. The following is her statement "Sometimes if I feel sad or anxious about my situation, I prefer to share it through blogs or articles like that... it is better to distribute it through writing or share the story with friends. What I am telling them is all kinds of things. What is clear is that they know me, and we have the same point of view". In addition to blog writing, she also likes watching Korean dramas entitled It's Okey Not To Be Okey and Unfamiliar Family. For informant

Jurnal ASPIKOM, Vol. 6, No. 2, July 2021, pp. 250-264 
Han, watching them is a distraction while simultaneously looking for entertainment. Informant Han also added that the meaning she got from the drama was "What I like this drama we are taught to be able to understand the situations and conditions, and also in the story there is an unexpected plot twist that turns out that what has been considered good from the outside is not necessarily a good heart either. So one of the lessons in life that I can learn from this story is that we shouldn't judge situations and conditions just at a glance but look at the meaning behind them, and also, most importantly, do not look at people only from the outside".

\section{Post Decision Dissonance Creates a Need for Reassurance}

Furthermore, according to Festinger, humans will look for efforts when their cognitive state is disrupted. These efforts are carried out as motivation to achieve consonance (Fadholi et al., 2020). This post dissonance is a substantial doubt that is experienced after someone makes an important decision. Three conditions can improve post-decisions, such as (1) the more significant the problem at hand, (2) the longer a person delays in choosing between the same two attractive options, and (3) the more significant the difficulty in restoring a decision where the decision has been made taken (Hinojosa et al., 2017). Informant Aul admitted that every life decision she made always thought about her parents and the environment. The following is her statement " $A u l$ likes to make decisions for a long time because Aul also thinks about my parents. Even though my parents have left it to me, I still think. And sometimes, I think about my uncle and my aunt, then the neighbors, hihihi. I am weird, but if they are in my life, I will think about their opinion too". Meanwhile, informant May explained similarly to informant Aul and informant Han that it is challenging to decide on your own because of the factors that influence them from their parents. Informant May said, "If I make the wrong decision, I'm afraid to disappoint others, especially my parents, and I only live just with my mom". Meanwhile, informant May explained similarly to informant Aul and informant Han, that it is difficult to decide on your own because of the factors that influence them from their parents. Informant May said, "If I make the wrong decision, I'm afraid to disappoint others, especially my parents, especially my moms" here, she prefers to tell and discuss it with my parents first. Suppose the parents disagree with the decision, then it will not be taken. Informant Han did the same thing.

With the statements conveyed by the three informants above, they have something in the standard regarding strong doubts when making and making important decisions. Informant May had previously worked as an investor in a company. However, she did not resume it because the opinion of a friend she knew said that the company was not good for its prospects. So, what had been conveyed was considered essential information for May, and she decided not to continue. In addition, the major she took did not feel suitable for her, so she forced herself to finish her studies with regret. Her regret started when she gave the department she liked to significant in Biology. Then she gave it to his friend. Meanwhile, she himself majored in Physics which she was less interested in. Friends who asked her not to enter, but May still join the Department of Physics. She had time to say what she thought and felt to his significant others, namely her mother. Her parents have already responded to invite her if she chooses to change majors, but she doubts her statement, so she decides to continue with self-compulsion. At this moment, she thinks and feels that she is worthless. Often, she does self-blaming. This causes his self-anxiety to increase. Eventually, the goal she wants to achieve becomes obstructed because her thoughts and feelings are anxious and restless. 
Informant Aul stated that she had always thought about how other people's thoughts and feelings about her were all this time. She even had the principle of self, 'it is better to make other people first, then her'. The existence of a regulation that she holds as self-confidence prevents her from making decisions. She wants to get out of this principle. Her effort is to follow Mba Analisa Widianingrum's YouTube channel as a reference to align what is blocking her mind and taste, or what is called cognitive dissonance. Informant Aul works as an administrator until now, but this is what she is worried about. If a question comes up from a neighbor, she is confused about answering. She admitted that her parents could accept her condition because informant Aul was more open with her mother. For her, the mother figure plays a huge role, and if she gives the input, Aul can accept it. However, she still always feels anxious and restless if she disappoints her mother.

Informant Han, is close to her parents, especially her mother. Until now, she has not found a job because of the COVID-19 pandemic conditions. Informant Han has made efforts to send CVs to various companies. The mindset that has been formed in her mind is that the environment will recognize a successful person and her existence if the person works in the company with a salary above the regional minimum wage. With this mindset, she channels her anxiety by writing blogs because her writing is better felt than telling stories. She does so because she avoided her extended family, who always asked where she worked. She felt significant doubt every time she wanted to make a decision on her own. It was difficult for him to decide on something because he always saw how his mother looked. Like informant May, her parent is a single parent, and because family values are still very strong in her family, this is what makes it difficult for informants to decide. Informant Aul also experienced this.

Bandura (1997) suggests that a person's self-efficacy can influence their actions to choose, determine business, and achieve a goal they want, as well as resilience in facing obstacles in live out his choice (Tangkeallo et al., 2014, p. 29). From the experience of these three informants, they will return the decision to their significant others so that this process affects their self-efficacy.

\section{Minimal Justification for Action Induces a Shift in Attitude}

The minimal justification hypothesis is a claim which is the best way to stimulate a change in a person's behavior by offering sufficient encouragement to obtain counter attitudinal behavior. When there is an opportunity to influence, it should be done with a strategy. In other words, in this third hypothesis, Festinger (Griffin, 2012, p. 222) states that someone must be able to change destructive behavior patterns into attitude formation. When correlated with the findings with informants, such as informant Aul, she said, "Currently, the role of my mother is huge for me. My mother helps to provide information about job vacancies. I felt there was support from my closest people. If the mother just said, 'OK, it is I will be in a comfortable condition. Because of the support information, Aul felt motivated to find work, such as being active in sending $C V$. Because soon, the decision for Aul's apprenticeship will be extended or not from the company is getting closer. This is what makes me nervous too". The statement conveyed could mean that informant Aul was moved to change her perspective from now on. She tried to change her anxious thoughts and feelings by changing her mindset strategy. There is a mother's role that she chooses as a support system, here, giving her enlightenment, apart from the YouTube channel she follow.

Meanwhile, informant May got out of the dissonance by sharing with her closest

Jurnal ASPIKOM, Vol. 6, No. 2, July 2021, pp. 250-264 
people, such as her mother and siblings. Also, she uses her consistent attitude to watch the YouTube channel Menjadi Manusia (Being Human), which she uses as a source of self-reinforcement. She limits self-disclosure to her peer groups. This attitude was taken by informant May, because according to her perception, many friends asked, where have you worked or where are you busy at? "There is a friend who just casually asks", where have you been working? "How do you feel like you have a job?" even though she knows that I have not worked yet but instead they asked about it. Yes, at the first time, there were often stories of closest friends because they felt we are the same. But in the end, I will not tell them anymore because they are different. I mean, from the worries, it must be different. But the condition after graduating like this makes me love myself, otherwise, everyone else should know about me. The circle of friends is getting smaller and clearer. I know myself more deeply and be at peace with myself'. Furthermore, the strategy that she applies to herself is worship that he does not abandon "a separate effort to worship because that is the key because of it, I am also afraid that it will end up running into things that are not supposed to be".".

Informant Han tried to join CPNS (civil servant) test. She believed this method to be able to penetrate and get out of his anxiety. Besides that, she also admitted that if she had the will, she would do it and try. "My recent activity is participating in the CPNS try-out. From the beginning, my intention and goal were to qualify to become a civil servant. So from now on, I am preparing myself for the CPNS exam in March next year". She reduced her blog writing activities because she referred to her previous statement that blogs were used as a channel for self-emotion when informant Han was feeling sad and anxious. The questions often asked to her from the extended family did impact and made her self-motivated to get out of this dissonance.

After linking the hypothesis of the three mental mechanisms with the results of this in-depth interview with iGeneration conservative, the researchers can explain that the informants made various efforts to align with the cognitive dissonance they experienced. They chose social media platforms to help them reference themselves. The information obtained will be selected, then processed, then interpreted. This process is included in the cognitive schemata owned by each informant. The findings of in-depth interviews with the informants show that from the selective used as an effort to reduce dissonance, selective exposure and particular attention are more dominant than selective retention and selective interpretation.

They also stated that one of the platforms that helped was YouTube compared to Instagram because this platform has a similar perspective -more image- when compared to YouTube. The existence of Instagram, where many peer groups with the same scope make social comparisons, creates their self-measuring value on the information they receive. Self-measuring values affect the image and define success as working in a company; otherwise, a person is considered unsuccessful. The impact is significant enough that they become increasingly self-aware and make overthinking. For example, the informants felt disturbed at their thoughts and feelings when people who knew them asked questions about how busy they were at the moment.

These informants have different backgrounds, but when they face the information related to the issue, they state that the issues affect life patterns and lifestyle; in this case, perspective and perception are also disturbed. The mind's focus becomes affected so that they limit themselves to social interactions, and they always arise a feeling of inferiority that comes among them. They sometimes feel less self-respecting because they prioritize family values. This makes it take a long time to decide because they will 
weigh their significant others' thoughts and feelings. The next effect is to affect their self-efficacy, self-disclosure, and self-awareness. If this continues, it will create symptoms of an inferiority complex, which has been said when Generation $\mathrm{Z}$ or iGeneration is vulnerable to stress. Next, it will be explained with a chart of the results processed by researchers:

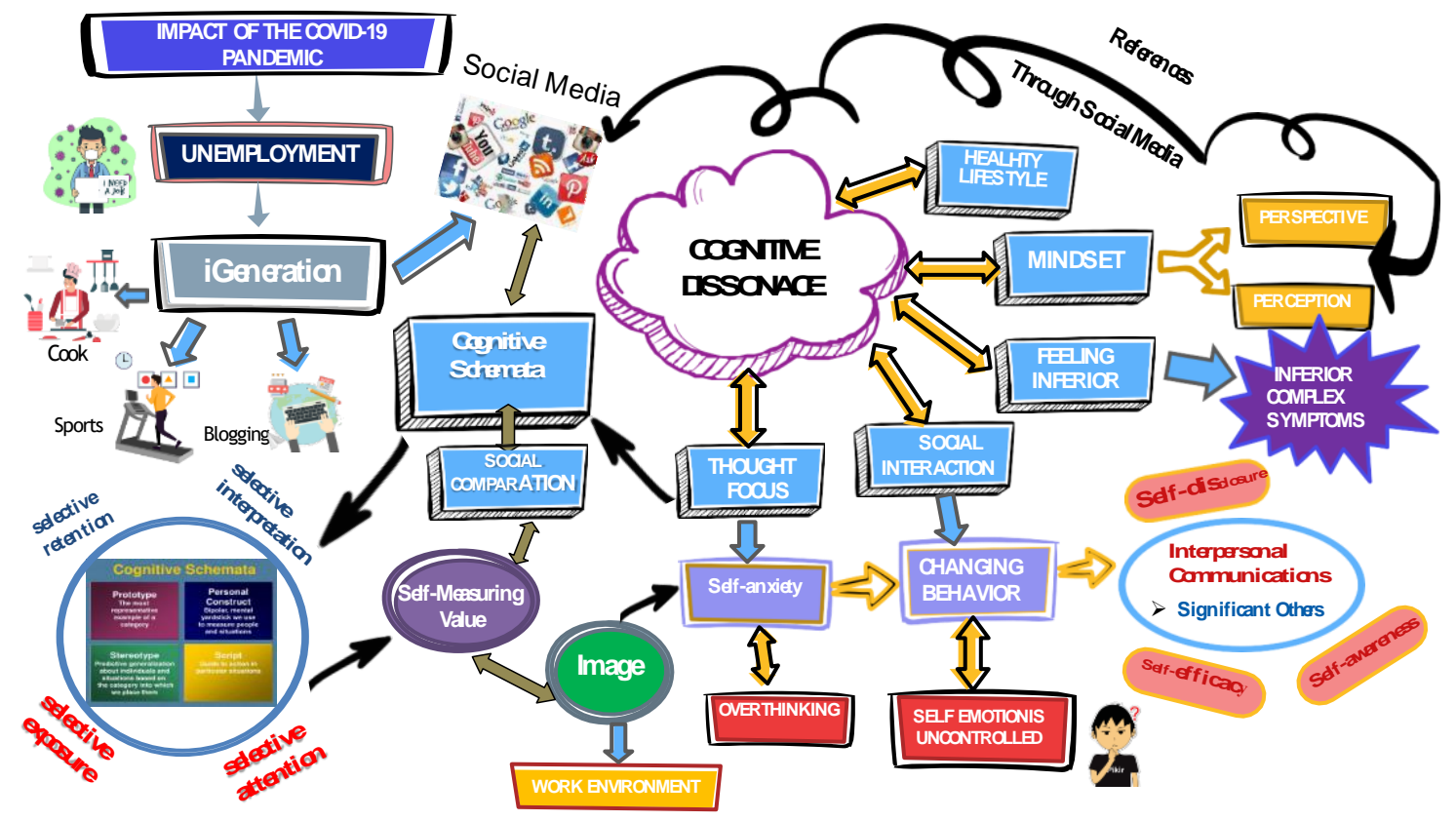

Figure 2. Research Analysis Framework

\section{Conclusion}

The research results showed that the informants who are iGeneration conservatives have certain levels of anxiety about the issue of not getting a job during the COVID-19 pandemic. Each of the informants is looking for ways or efforts to motivate themselves and find harmony in their absurd thoughts regarding their anxiety. Some are done through effective interpersonal communication interactions with their significant others, such as by carrying out self-disclosure and self-awareness which increases self-efficacy. The hypothesis of three mental mechanisms from Festinger's cognitive dissonance theory (West \& Turner, 2010), namely selective prevents dissonance, states that these informants avoid information that makes them uncomfortable. Hence, they select the information received by looking for efforts to harmonize it in various ways.

Furthermore, post-decision dissonance creates a need for reassurance. In this hypothesis, informants admit that there are strong doubts in making important decisions with the need for encouragement and prior discussion with the people closest to them, one of which is the parents who influence. Furthermore, in the decision-making process, where they will return the decision to their significant others, this process affects their self-efficacy. Finally, at least justification for action induces a shift in attitude, which is the process of changing lousy behavior patterns into attitude formation, where each of these informants has their way to get out of this dissonance with strategies as business motivation or effort, as well as the role of the supporting system. 


\section{Acknowledgements}

Researchers would like to thank the ASPIKOM Journal (Indonesian Association of Communications Science Higher Education) for their willingness to facilitate the dissemination of this research. Furthermore, this gratitude is also addressed to Bakrie University who supports the smooth running of this research. The researchers do not forget to thank again the informants, namely Aul, Han, and May, who are willing to take their time to become resource persons in this research. Even though there are limitations in communication carried out in a virtual due to the COVID-19 pandemic, it still does not reduce the in-depth interview process carried out.

\section{References}

Achmad, R. A., Firdayati, A., Psikologi, P. S., Kedokteran, F., Mangkurat, U. L., Yani, J. A., \& Selatan, B. K. (2019). Cognitive Dissonance in Women Who Are Addicted to Pornography. https://ppjp.ulm.ac.id/journal/index.php/ecopsy/article/view/6028

Fadholi, F., Prisanto, G. F., Ernungtyas, N. F., Irwansyah, I., \& Hasna, S. (2020). Disonansi Kognitif Perokok Aktif di Indonesia. Jurnal RAP (Riset Aktual Psikologi Universitas Negeri Padang), 11(1). https://doi.org/10.24036/rapun.v11i1.108039

Ginting, P. A. (2018). Implementasi Teori Maslow dan Peran Ganda Pekerja Wanita K3L Universitas Padajajaran. Focus: Jurnal Pekerjaan Sosial, 1(3), 220. https://doi.org/10.24198/focus.v1i3.20498

Griffin, E. (2012). A First Look at Communication Theory Eight Edition. New York: McGraw-Hill.

Hinojosa, A. S., Gardner, W. L., Walker, H. J., Cogliser, C., \& Gullifor, D. (2017). A Review of Cognitive Dissonance Theory in Management Research: Opportunities for Further Development. Journal of Management, 43(1). https://doi.org/10.1177/0149206316668236

Hutagalung, I. (2016). Disonansi Kognitif Pada Perilaku Seks Pranikah. Jurnal Komunikasi Ikatan Sarjana Komunikasi Indonesia, 1(2). https://doi.org/10.25008/jkiski.v1i2.52

Limilia, P., \& Pratamawaty, B. B. (2020). Google Trends and Information Seeking Trend of COVID-19 in Indonesia. Jurnal ASPIKOM, 5(2). https://doi.org/10.24329/aspikom.v5i2.741

Linnes, C., \& Metcalf, B. (2017). iGeneration And Their Acceptance of Technology. International Journal of Management \& Information Systems (IJMIS), 21(2). https://doi.org/10.19030/ijmis.v21i2.10073

Lusiawati, I. (2019). Public Service in Interpersonal Communication. International Journal for Educational and Vocational Studies, 1(5), 484-488. https://doi.org/10.29103/ijevs.v1i5.1719

Metin, I., \& Camgoz, S. (2011). The advances in the history of cognitive dissonance theory. International Journal of Humanities and Social, 1(6)

Nafi-an, I. (2020, November 8). Alasan Anies Kembali Perpanjang Masa PSBB Transisi hingga 22 November. https://news.detik.com/berita/d-5246640/alasananies-kembali-perpanjang-masa-psbb-transisi-hingga-22-november

Nihayati, N., \& Laksmi, L. (2020). Perilaku pencarian informasi pekerjaan oleh sarjana fresh graduate dengan analisis Model Wilson. Berkala Ilmu Perpustakaan Dan Informasi, 16(1). https://doi.org/10.22146/bip.v16i1.171 
Pambayun, E. L. (2013). One stop Qualitative research methodology in communication: Konsep, panduan, dan aplikasi. Jakarta: Lentera Ilmu.

Prihatsanti, U., Suryanto, S., \& Hendriani, W. (2018). Menggunakan Studi Kasus sebagai Metode Ilmiah dalam Psikologi. Buletin Psikologi, 26(2). https://doi.org/10.22146/buletinpsikologi.38895

Putri, C. A. (2020, May 4). Sri Mulyani Ungkap Ngerinya Ekonomi RI Diserang Covid19. https://www.cnbcindonesia.com/news/20200504132842-4-156067/srimulyani-ungkap-ngerinya-ekonomi-ri-diserang-covid-19

Qurniawati, R. S., \& Nurohman, Y. A. (2018). eWom pada Generasi Z di Sosial Media. Jurnal Manajemen Dayasaing, 20(2).

Rachmawati, D. (2019). Selamat datang generasi z di dunia kerja. Proceeding Indonesia Career Center Network, IV.

Rahmi, F. (2019). Efikasi Diri Dalam Membuat Keputusan Karier Pada Mahasiswa. Insight: Jurnal Ilmiah Psikologi, https://doi.org/10.26486/psikologi.v21i1.756

Rakhmat, J. (2015). Psikologi Komunikasi. Simbiosa Rakatama Media.

Rashid, Y., Rashid, A., Warraich, M. A., Sabir, S. S., \& Waseem, A. (2019). Case Study Method: A Step-by-Step Guide for Business Researchers. International Journal of Qualitative Methods, 18. https://doi.org/10.1177/1609406919862424

Reddan, G. (2015). Enhancing students' self-efficacy in making positive career decisions. Asia-Pacific Journal of Cooperative Education, 16(4), 291-300.

Rosito, A. C. (2018). Kepribadian dan Self-Regulated Learning. Jurnal Psikologi, 45(3), 189. https://doi.org/10.22146/jpsi.28530

Rosyanti, L., \& Hadi, I. (2020). Dampak Psikologis dalam Memberikan Perawatan dan Layanan Kesehatan Pasien COVID-19 pada Tenaga Profesional Kesehatan. Health Information: Jurnal Penelitian, 12(1), 107-130. https://doi.org/10.36990/hijp.vi.191

Sarwono, S. W. (2010). Teori-teori Psikologi Sosial. Jakarta: Rajawali.

Setiyani, W. (2017). Implementasi Psikologi Humanistik Carl Rogers pada Tradisi Lokal Nyadran di Jambe Gemarang Kedunggalar Ngawi. 12(September).

Shafira, G. R., \& Soedirham, O. (2017). Gambaran Dimensi Internal Dalam Konsep Diri Anak Asuh UPTD Kampung Anak Negeri Surabaya. https://doi.org/10.20473/ijph.v12i1.2017.154-166

Slavin, A. (2015). Marketers: Forget about Millennials. Gen Z Has Arrived. http://women2.com/2015/08/07/engage-gen-Z-users/?hvid=5LyrgK

Srisayekti, W., \& Setiady, D. A. (2015). Harga-diri (Self-esteem) Terancam dan Perilaku Menghindar. Jurnal Psikologi, 42(2). https://doi.org/10.22146/jpsi.7169

Stephen W. Littlejohn, K. A. F. (2009). Encyclopedia of Communication Theory, Volume 1.

Sutarmanto, I. D. A. M. J. \& H. (2017). Disonansi Kognitif Gay Terkait Budaya Patrilineal di Bali. Gadjah Mada Journal of Psychology, Volume 3.

Tangkeallo, G. A., Purbojo, R., \& Sitorus, K. S. (2014). Hubungan Antara Self-Efficacy Dengan Orientasi Masa Depan Mahasiswa Tingkat Akhir. Jurnal Psikologi UIN Sultan Syarif Kasim Riau, 10(Juni).

West, R., \& Turner, L. (2010). Introducing Communication Theory: Analysis and Application (4th Ed). New York: McGraw-Hill.

Wijoyo, H., Indrawan, I., Cahyono, Y., Handoko, A. L., \& Santamoko, R. (2020). Generasi Z dan Revolusi Industri 4.0 (Vol. 1, Issue August). 
Yahya, A. H., \& Sukmayadi, V. (2020). A Review of Cognitive Dissonance Theory and Its Relevance to Current Social Issues. MIMBAR: Jurnal Sosial Dan Pembangunan, 36(2), 480-488. https://doi.org/10.29313/mimbar.v36i2.6652 